\title{
Agriculture Performance and Future Outlook on Food Commodities in Kerala ${ }^{\S}$
}

\author{
Shinoj Parappurathu \\ Department of Socio-economic Evaluation and Technology Transfer \\ ICAR-Central Marine Fisheries Research Institute, Kochi - 682 018, Kerala
}

\begin{abstract}
The paper has provided insights on the performance of Kerala's agricultural sector with emphasis on demand and supply position of major crops. The study is based on secondary data collected from different sources such as National Accounts Statistics, Farm Guide, Report on Cost of Cultivation of Important Crops in Kerala, NSSO surveys, etc. largely for the period 2000-01 to 2009-10. The study has revealed that Kerala has lost a considerable area under essential food crops like paddy, pulses, tapioca, vegetables, etc. as well as under high-value crops like cashewnut, spices, tea, coffee, etc. The high returns obtained from commercial crops and non-agriculture sector are being utilized for funding imports from other states to meet the demand for food commodities. The projections for supply-demand balance of food commodities undertaken in this study have reinforced that Kerala's self-sufficiency in most food commodities would touch worst levels. The study has advocated for a comprehensive agricultural development strategy for the state.
\end{abstract}

Key words: Agriculture performance, food commodities, supply-demand projections, food security, Kerala

JEL Classification: Q11, Q18

\section{Introduction}

The state of Kerala has remained at the centre of economic development discourse in the country for quite some time on several counts. First, the development model of Kerala has been divergent from that of most other state economies with the paradox of high human development together with low per capita income (Kannan, 1990; 1999; Tharamangalam, 1998; Parayil, 1998). Second, the inability of much celebrated 'land reforms' to ensure the possession of land by the

\footnotetext{
* Author for correspondence

Email: pshinoj@gmail.com

$\S$ This paper draws from the Background Paper on Agriculture, prepared by the author for State Planning Board, Government of Kerala on behalf of National Council of Applied Economic Research (NCAER), New Delhi. A part of the paper is featured in Kerala Perspective Plan 2030 (Volume I, Chapter 5).
}

actual tillers, leading to high level of food dependence and a thriving lease market (Balakrishnanan, 2008; Nair and Menon, 2006; Scaria, 2010). Third, the high levels of skilled out-migration that resulted, on the one hand, in a substantial flow of foreign remittances contributing to the state's development, and on the other hand, leading to alienation of families, sectoral imbalances in labour and increase in wage rates (Harilal and Joseph, 2003; Prakash, 1998; Zachariah and Irudaya Rajan, 2007). Fourth, the unfolding structural transformation from a grossly agrarian one, dominated by agriculture for income and employment, to a non-agrarian one, dominated by non-agrarian activities (Kannan, 2011). Fifth, the agrarian crisis and distress driven by global recession and neoliberal policy reforms that exposed its relatively protected niche crops to external competition (Mohanakumar and Sharma, 2006; Oommen, 2008). Sixth, the factors like high cost of 
cultivation, shortage of agricultural labour, undue concentration of commercial crops at the cost of food crops like paddy, decrease in size of farm holdings, competition from low priced imports, etc. that pull the farmers away from farming (Jeromi, 2003; 2005).

Despite several above-mentioned weaknesses, Kerala stands out on account of the recent turn around in its growth and a number of success stories that put it back on a high growth path with continuous improvements in social development indicators and living standards (Kannan, 2005; Chakraborty, 2005). In fact, Kerala seems to be capitalizing on its earlier achievements in education and health care to its favour. The GDP of Kerala has been increasing at an average rate of 7 per cent per annum during the past one decade and growth has been particularly impressive during the past five years.

Kerala's development conundrum has been closely intermingled with the performance of its agricultural sector from time to time. As Kannan (2011) has rightly pointed out, Kerala economy is undergoing a rapid transformation from a predominantly agrarian state to a heavily service-oriented economy. The share of agricultural and allied sector in gross state domestic product has declined steeply, from 32.6 per cent in 1980-81 to 10.6 per cent in 2010-11, while that of service sector got inflated from 45.4 per cent to 68.8 per cent during the same period.

The workforce engaged in agricultural activities also underwent a perceivable reduction with its share in total workforce sliding from 28.2 per cent in 1981 to 16.1 per cent in 2011. Even though, this transition has helped a part of disguisedly unemployed people engaged in the primary sector to get shifted to better earning secondary and tertiary activities, this is lately turning out to be a serious challenge in the form of shortage of labour for agricultural activities. Even though, improved educational opportunities and overseas migration prospects contributed to this exodus away from agriculture, the agrarian distress that originated towards the late-1990s had a major impact on the people to shift priorities. The resultant structural transformation had its foremost implication in the form of heightened dependence of the state for food on the neighbouring producing centres. Presently, Kerala depends on Andhra Pradesh for a considerable part of its requirement of rice, on Tamil Nadu for vegetables and on Karnataka for meat and milk. Lately, there have been concerns brewing over this increasing dependence on others for essential food that could, at some point of time, risk the sustainability of the state's development process.

As far as future development of the state is concerned, Kerala is caught in a high stake policy dilemma on whether to allow its high incomegenerating service-oriented activities to continue its course at the cost of losing food self-sufficiency and agricultural bankruptcy, or to undertake a course correction to protect its primary sector even with some compromise on the pace of growth. In this backdrop, this study has been undertaken with the primary objective of providing insights on the performance of Kerala's agricultural sector, with emphasis on demand and supply position of major crops.

\section{Performance of Kerala Agriculture}

\section{Sectoral Growth}

The estimates of annual trend growth rates in gross domestic product of agriculture, forestry and fishery sectors along with that of overall agriculture and allied sector and non-agricultural sector in Kerala are presented in Table 1 . The estimates show that agriculture (including livestock) had a modest growth of 2.53 per cent during the 1990s, but displayed poor performance $(0.27 \%)$ during the decade of 2000s. A similar deceleration in growth was noticed in forestry and logging sector too, but the fishery sector

Table 1. Trend growth rates in GDP (2004-05 Prices) of various sub-sectors in Kerala

(Per cent)

\begin{tabular}{lccc}
\hline Sector & $\begin{array}{c}1990-91 \\
\text { to } \\
1999-00\end{array}$ & $\begin{array}{c}2000-01 \\
\text { to } \\
2010-11\end{array}$ & $\begin{array}{c}1990-91 \\
\text { to } \\
2010-11\end{array}$ \\
\hline Agriculture* $_{\text {Forestry and logging }}$ & 2.53 & 0.27 & 1.28 \\
Fishery & 3.69 & 2.00 & 2.31 \\
Agriculture and allied & -0.37 & 0.32 & 0.35 \\
Non-agriculture & 2.34 & 0.46 & 1.29 \\
All sectors & 6.24 & 9.41 & 7.53 \\
\hline
\end{tabular}

Note: *GDP Agriculture includes both crops and livestock. Data source: National Accounts Statistics, Central Statistical Organization, Government of India 
experienced a slight improvement in growth from 0.37 per cent to 0.32 per cent. The shoddy performance in agriculture and forestry got reflected in the agriculture and allied sector too with its growth sliding from 2.34 per cent in 1990s to an almost stagnant rate of 0.46 per cent in the succeeding decade. On the contrary, the non-agricultural sector registered an impressive growth during both the periods, the latter period outshining the former. In general, it can be concluded that agriculture and allied sector in Kerala experienced a set back during the previous decade with all its sub-sectors losing vigour in growth, whereas nonagricultural sector gained momentum in growth during this period.

The performance of major crop groups in Kerala was captured using annual trend growth rates in their value of product (VOP) corresponding to three periods viz. 1990-91 to 1999-00, 2000-01 to 2008-09 and 199091 to 2008-09. A cursory glance at the results suggests that all crop categories demonstrated visible deceleration in growth during the 2000s in relation to their status in the previous decade. While cereals, pulses, fruits and vegetables and drugs and narcotics registered negative growths, the growth in oilseeds was near stagnancy. Cereals, with paddy as the major constituent, displayed negative growth rates of -4.82 per cent and -2.57 per cent during 1990s and 2000s, respectively (Table 2). The substantial deceleration in the value of output of pulses (-23.82 \%) and drugs and narcotics $(-7.89 \%)$ is particularly noteworthy.

Table 2. Trend growth in value of product (VOP) (200405 prices) of major crops in Kerala

(Per cent)

\begin{tabular}{lccc}
\hline Sector & $\begin{array}{c}1990-91 \\
\text { to } \\
1999-00\end{array}$ & $\begin{array}{c}2000-01 \\
\text { to } \\
2008-09\end{array}$ & $\begin{array}{c}1990-91 \\
\text { to } \\
2008-09\end{array}$ \\
\hline Cereals & -4.82 & -2.57 & -3.64 \\
Pulses & 2.05 & -23.82 & -13.69 \\
Oilseeds & 2.53 & 0.77 & 1.13 \\
Spices and condiments & 2.49 & 2.47 & 3.34 \\
Fruits and vegetables & 2.23 & -1.55 & -0.22 \\
Drugs and narcotics & 8.86 & -7.89 & 2.38 \\
All crops & 2.61 & 0.57 & 1.51 \\
\hline
\end{tabular}

Data source: National Accounts Statistics, Central Statistical Organization, Government of India.
To understand individual performance of major crops during the periods under consideration, the trend growth rates in their area, production and yield were estimated and are presented in Table 3. Taken together, these crops accounted for 82 per cent of GCA in Kerala. As noted previously, the decade after 2000 was particularly disastrous for most of the crops like rice, coconut, tapioca, cashewnut, pepper, ginger, cardamom, tea, etc., with area under them declining substantially. In some crops like rice, coconut, tapioca, cashewnut, ginger, etc. improvements in crop productivity helped in offsetting the decline in production to a certain extent. However, in crops like pepper, cardamom, tea and coffee, the yield levels also declined resulting in exponential decline in their production. Rice, the major cereal grown in the state, experienced a conspicuous negative growth in area and production throughout 1990s and 2000s. Evidently, the crop registered an overall growth rate of -4.92 per cent in area and -3.64 per cent in production during the period 1990-91 to 2010-11.

On the contrary, a few crops like rubber and banana displayed impressive performance. For instance, area under rubber grew at the rate of 1.10 per cent per annum during the past two decades and together with a growth in yield at the rate of 3.38 per cent, rubber production increased at a substantial rate of 4.51 per cent per year. Similarly, banana experienced a surge in area the rate of 3.31 per cent during the 1990s. The yield improvement in banana was also remarkable, so that its production went up at the rate of 10.04 per cent annually during this period. The performance of this crop was subdued in the subsequent decade but between 1990-91 and 2010-11, banana consolidated an impressive escalation in its area and production. One major reason behind this could be the conversion of paddy land for cultivation of banana and increased use of inputs, the latter being a more profitable crop in the recent years. Another crop that received a boost in production during the 1990s was coffee, particularly due to improvement in productivity, but these gains were negated in the subsequent decade, limiting its overall performance. Cardamom also depicted a more or less similar pattern in growth in area and production.

A general inference that can be discerned from the above analysis is that agriculture in Kerala has suffered considerable set back in recent years, particularly in terms of loss in area and decline in production of major 
Table 3. Trend growth in area, production and yield of major crops in Kerala

(Per cent)

\begin{tabular}{|c|c|c|c|c|c|c|c|c|c|}
\hline \multirow[t]{2}{*}{ Crop } & \multicolumn{3}{|c|}{$1990-91$ to $1999-00$} & \multicolumn{3}{|c|}{$2000-01$ to $2010-11$} & \multicolumn{3}{|c|}{$1990-91$ to $2010-11$} \\
\hline & Area & Production & Yield & Area & Production & Yield & Area & Production & Yield \\
\hline Rice & -5.55 & -4.74 & 0.87 & -4.55 & -2.79 & 1.84 & -4.92 & -3.64 & 1.34 \\
\hline Coconut & 0.34 & 1.61 & 1.26 & -1.92 & -0.11 & 1.85 & -0.49 & 1.12 & 1.62 \\
\hline Rubber & 1.41 & 7.35 & 5.85 & 1.31 & 3.37 & 2.04 & 1.10 & 4.51 & 3.38 \\
\hline Таріоса & -2.30 & -0.09 & 2.26 & -4.19 & 0.15 & 4.54 & -3.17 & -0.30 & 2.96 \\
\hline Arecanut & 2.92 & 3.48 & 1.26 & 0.73 & 2.11 & 1.27 & 2.83 & 2.63 & -0.13 \\
\hline Cashewnut & -3.12 & -6.91 & -3.91 & -7.48 & -6.52 & 1.03 & -3.99 & -4.31 & -0.33 \\
\hline Banana & 3.31 & 10.04 & 6.51 & 0.01 & 1.04 & 1.04 & 3.30 & 4.25 & 0.92 \\
\hline Pepper & 0.52 & 2.46 & 1.93 & -2.65 & -5.26 & -2.69 & 0.26 & -0.26 & -0.51 \\
\hline Ginger & -1.55 & -0.36 & 1.21 & -5.60 & -2.63 & 3.15 & -3.75 & -1.86 & 1.96 \\
\hline Cardamom & -0.83 & 7.97 & 8.87 & -0.05 & -0.54 & -0.50 & -0.35 & 5.38 & 5.75 \\
\hline Tea & 0.36 & 0.92 & 0.56 & -0.05 & -1.65 & -1.59 & 0.30 & -0.97 & -1.27 \\
\hline Coffee & 0.59 & 12.61 & 11.95 & 0.04 & -1.44 & -1.48 & 0.25 & 4.02 & 3.76 \\
\hline
\end{tabular}

Data source: Farm Guide, 2012, Farm Information Bureau, Government of Kerala.

crops. There is a general trend of moving away from food crops like paddy, coconut, tapioca, etc. towards more profitable and commercial crops like rubber. The declining productivity in some niche crops like pepper, cashewnut, tea, etc. is also a cause of concern. The silver lining is that some crops like paddy, coconut, tapioca, ginger, etc. have managed to improve their productivity even in the midst of losing share in area and general aversion of farmers to cultivate them.

\section{Total Factor Productivity of Crops}

The growth in total factor productivity (TFP) of major crops was estimated to understand the trends in intrinsic productivity of crops which is not attributed to increase in input use or growth in nominal prices, but on account of improvement in technology, management practices, or other exogenous factors like institutional innovations in crop management. Technically, TFP measures the amount of increase in the total output, which is not accounted for by increases in the total inputs. It is the ratio of an index of aggregate output to an index of aggregate input. One of the most popular methods, namely, Divisia Tornqvist, was used in this study to estimate TFP. The detailed methodological framework and the approach followed for computation of the index in the present context are detailed in Appendix 1. In the case of paddy, growth in input index during 2000-01 to 2009-10 was estimated to be -0.44 per cent, mainly on account of reduced use of human labour which is the major input in paddy cultivation (Table 4). This could be due to the increase in wages of human labour which got eventually replaced with machine labour to a substantial extend.

At the same time, output per unit of area of paddy increased at the rate of 1.39 per cent owing to increased use of high-yielding varieties. This is evident from the fact that share of area under HYV of paddy increased from 65.1 per cent to 91.2 per cent during the previous decade. The TFP of paddy grew at the rate of 1.84 per cent, suggesting that improvement in technology and management in paddy had in fact brought about an increase in its intrinsic productivity. In the case of coconut, use of inputs grew at the rate of 1.27 per cent per annum, while output per hectare increased at the rate of 2.04 per cent, leading to a positive growth in TFP at the rate of 0.77 per cent. It was found that the share of TFP growth in total output growth in coconut was 38 per cent during the period under study.

Tapioca is another major crop of Kerala that has shown tremendous improvement in TFP owing to a considerable growth in output (4.92\%) in relation to input growth at the rate of 1.27 per cent. Here, TFP contributed a higher share (73.5\%) to growth in output. A positive, but modest growth in TFP $(0.81 \%)$ was also observed in the case of banana, where it 
Parappurathu : Agriculture Performance and Future Outlook on Food Commodities in Kerala

Table 4. Annual growth in inputs, output, TFP and real cost of production for major crops in Kerala, 2000-01 to 2009-10

(Per cent)

\begin{tabular}{lccccc}
\hline Crop & $\begin{array}{c}\text { Input } \\
\text { growth }\end{array}$ & $\begin{array}{c}\text { Output } \\
\text { growth }\end{array}$ & $\begin{array}{c}\text { TFP } \\
\text { growth }\end{array}$ & $\begin{array}{c}\text { Growth in real cost } \\
\text { of cultivation (Cost A) }\end{array}$ & $\begin{array}{c}\text { Share of TFP growth } \\
\text { in output growth }\end{array}$ \\
\hline Paddy $^{*}$ & -0.44 & 1.39 & 1.84 & 0.09 & 100 \\
Coconut & 1.27 & 2.04 & 0.76 & 4.61 & 38.0 \\
Tapioca & 1.27 & 4.92 & 3.60 & 1.65 & 73.5 \\
Banana & 0.40 & 1.21 & 0.81 & -3.26 & 66.9 \\
Pepper & 3.16 & -3.83 & -6.78 & 3.18 & $(-\mathrm{ve})$ \\
Ginger & 3.38 & 2.48 & -0.77 & 2.83 & (-ve) \\
Turmeric & 1.47 & 1.97 & 0.49 & -1.44 & 24.5 \\
\hline
\end{tabular}

Data source: Report on Cost of Cultivation of Important Crops in Kerala (various years). Department of Economic and Statistics, Government of Kerala. The data on paddy was taken from CACP reports published by Government of India.

Notes: * Results for paddy correspond to the period 1997-98 to 2009-10.

Computed by author using Divisia Tornqvist or translog index of TFP.

contributed 66.9 per cent to total output growth. However, spice crops like pepper and ginger, exhibited a negative growth in TFP as a result of higher rate of input growth in relation to output growth. In fact, output per hectare in pepper decreased at the rate of -3.83 per cent, while use of inputs increased at the rate of 3.16 per cent, taking the estimated value of TFP growth to -6.78 per cent. In ginger, TFP growth was -0.77 per cent, lower than that of pepper. Turmeric showed a improvement in TFP at 0.49 per cent per annum, that accounted for 24.5 per cent of total growth in output.

\section{Demand and Supply Outlook of Food Commodities}

This section deals with the trends in consumption pattern of major food items, existing availability of various food items, level of self-sufficiency and future outlook on demand and supply of major food items in Kerala.

\section{Baseline Demand and Supply}

Kerala is no exception to the phenomenon of dietary diversification that has been unfolding in India over the past few decades. There is abundant literature that gives sufficient proof on the increasing preference of people towards high-value commodities like fruits and vegetables, milk, meat, egg, fish, etc., over the traditional commodities like cereals, pulses and tubers (Kumar et al., 2006; 2007; Joshi et al., 2006; 2008). In a similar fashion, the food consumption pattern of people of Kerala has also undergone a gradual transformation over the years which can be attributed to a number of factors like rising per capita income, urbanization and resultant changes in life-style, health consciousness, etc. Table 5 presents the per capita consumption of major food items in Kerala for three points of time, viz. 1999-00, 2004-05 and 2009-10. The data pertains to the reports of the National Sample Survey Organization (NSSO) for the $55^{\text {th }}, 61^{\text {th }}$ and $66^{\text {th }}$ rounds of surveys, respectively.

The estimates given in Table 5 suggest that consumption of rice decreased from $105.4 \mathrm{~kg} /$ capita/ annum in 1999-00 to $90.6 \mathrm{~kg} / \mathrm{capita} / \mathrm{annum}$ in 200910 , the change being very conspicuous. In the case of wheat, the consumption decreased slightly from 12.5 $\mathrm{kg} /$ capita in 1999-00 to $11.9 \mathrm{~kg} /$ capita in 2004-05, but increased to $12.7 \mathrm{~kg} /$ capita by 2009-10. This finding is relevant in the sense that it indicates a slow shift of Kerala people from rice-based food preparations to wheat-based preparations like chapatti and bread. The pulse consumption remained more or less same during the three periods, whereas consumption of edible oil increased at perceptible levels. In the case of fruits and vegetables, the increase in consumption had been more abrupt. Vegetables consumption increased from 43.7 $\mathrm{kg} /$ capita to $58.3 \mathrm{~kg} /$ capita during the 10 -year period from 1999-00. Fruit demand also increased at a similar pace from $32.4 \mathrm{~kg} /$ capita in 2004-05 to $39.1 \mathrm{~kg} /$ capita 
Table 5. Trends in consumption of major food commodities in Kerala

\begin{tabular}{lccc}
\hline \multirow{2}{*}{ Food } & \multicolumn{3}{c}{ Consumption (kg/capita/annum) } \\
\cline { 2 - 4 } & $1999-00$ & $2004-05$ & $2009-10$ \\
\hline Rice & 105.4 & 100.2 & 90.6 \\
Wheat & 12.5 & 11.9 & 12.7 \\
Pulses & 7.1 & 7.3 & 7.4 \\
Edible oils & 5.2 & 5.3 & 6.6 \\
Vegetables & 43.7 & 45.7 & 58.3 \\
Fruits & NA & 32.4 & 39.1 \\
Spices & 4.9 & 4.1 & 7.1 \\
\hline
\end{tabular}

Data Source: Reports of NSSO for the $55^{\text {th, }} 61^{\text {th }}$ and $66^{\text {th }}$ rounds of surveys.

in 2009-10. Spices demand decreased in 2004-05, in relation to that of 1999-00, but experienced a boost afterwards. In nutshell, it can be concluded that Kerala's food consumption pattern also experienced a clear diversification towards high-value commodities, as has happened in rest of India.

Based on the latest estimates on per capita consumption, the total demands for major commodities at the state level were computed and are presented in Table 6. The total demand consists of both household demand (direct demand) as well as indirect demand. Indirect demand arises mainly from consumption outside the households, industrial uses, use as seed and feed, loss as wastage, etc. In the present context, the estimates on indirect demand were arrived based on similar calculations undertaken during past studies
(Kumar et al., 2011). Accordingly, the total demand estimates were worked out to be 3,558.9 thousand tonnes for rice, 524.2 thousand tonnes for wheat and 428.8 thousand tonnes for pulses. The demand for edible oils comes around 296.4 thousand tonnes and comprises of all types of edible oils used in the state, including those are imported. The vegetables demand in Kerala in the year 2009-10 was assessed to be 2,713.2 thousand tonnes, whereas the demand for fruits and spices was 1,774.2 thousand tonnes and 282.5 thousand tonnes, respectively.

To assess how well the production of a commodity matched with its demand estimates, the production figures corresponding to the biennium ending (BE) 2009-10 are also presented in Table 6. It was observed that production fell short of demand in almost all food commodities, except for fruits in Kerala. In terms of production as a per cent of demand, the food grains such as rice, wheat, pulses, etc., fared poorly. The level of self-sufficiency for rice was only 16.7 per cent (Figure 1), the rest of the demand being met through imports from neighboring states like Andhra Pradesh and Tamil Nadu.

Since Kerala doesn’t produce wheat but consumes it in reasonable quantities, the entire wheat demand was met from north Indian states through inter-state trade and the case of pulses was no different. Selfsufficiency in vegetables was to the level of 36.6 per cent, and for spices was 35.5 per cent. Kerala produced more fruits than it consumed with the major share coming from fruits such as banana, mango, papaya,

Table 6. Base-year demand for major food commodities in Kerala, 2009-10

\begin{tabular}{lccccc}
\hline Commodity & $\begin{array}{c}\text { Per capita } \\
\text { household } \\
\text { consumption } \\
\text { (kg/capita/annum) }\end{array}$ & $\begin{array}{c}\text { Total household } \\
\text { demand } \\
\text { ('000 tonnes) }\end{array}$ & $\begin{array}{c}\text { Indirect } \\
\text { demand } \\
\text { ('000 tonnes) }\end{array}$ & $\begin{array}{c}\text { Total } \\
\text { demand } \\
\text { ('000 tonnes) }\end{array}$ & $\begin{array}{c}\text { Production }^{*} \\
\text { ('000 tonnes) }\end{array}$ \\
\hline Rice & 90.6 & 3085.6 & 473.2 & 3558.9 & 594.3 \\
Wheat & 12.7 & 432.4 & 91.8 & 524.2 & 0.0 \\
Pulses & 7.4 & 252.1 & 176.7 & 428.8 & 3.3 \\
Edible oil & 6.6 & 223.8 & 72.6 & 296.4 & $\mathrm{NA}$ \\
Vegetables & 58.3 & 1984.4 & 728.8 & 2713.2 & 993.2 \\
Fruits & 39.1 & 1330.6 & 443.5 & 1774.2 & 2398.1 \\
Spices & 7.1 & 240.2 & 42.4 & 282.5 & 100.4 \\
\hline
\end{tabular}

\#Corresponds to BE 2009-10. 


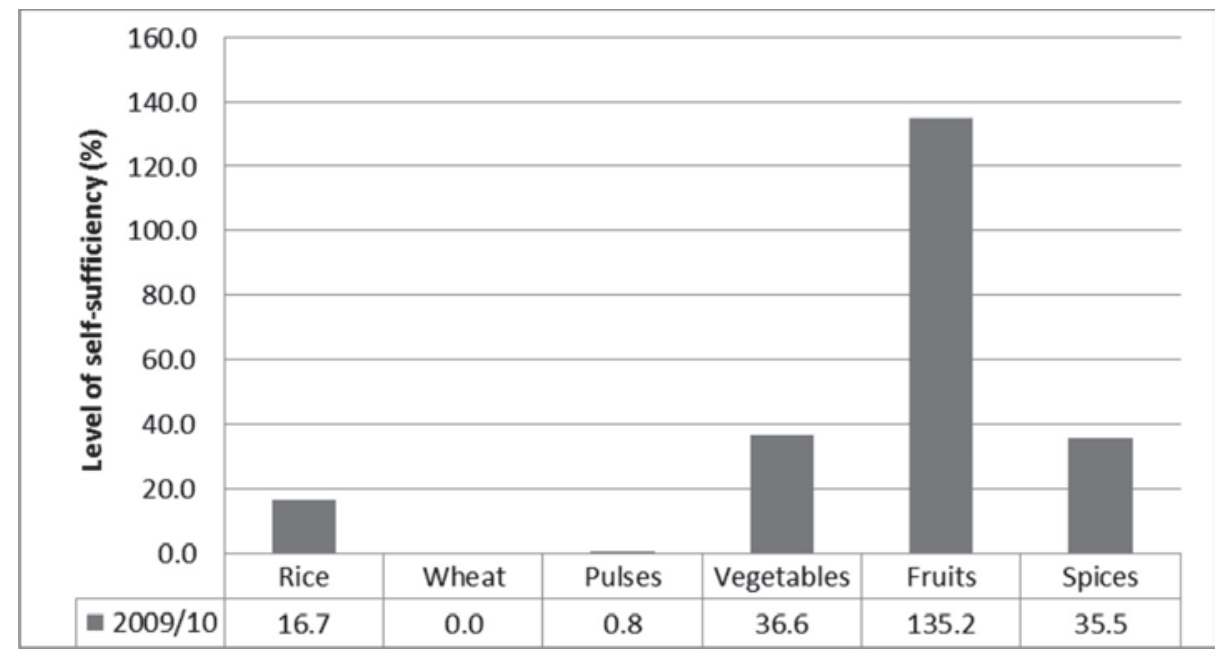

Figure 1. Level of self-sufficiency (per cent) for major food items in Kerala, 2009-10

pineapple, jack fruit, etc. However, it depends on imports to meet the demand for other types of cool season fruits even as it exports considerable quantities of its own produced ones to other states. The case of edible oils is not discussed here for want of credible estimates on internal production of this commodity.

\section{Demand Projections to 2030}

The detailed methodology used for demand projections, projected population and per capita income and income elasticities of demand for the commodities are presented in Appendices, 2-4. In the present context, demand projections for major food commodities such as food grains, fruits and vegetables, edible oils, spices, etc. were computed by taking 2010 as the base-year of projections. Accordingly, the demand projections for the years 2010, 2015, 2020, 2025 and 2030 for the above set of commodities are presented in Table 7 .
The results show that demand for rice would increase from the base-year value of 3567.5 thousand tonnes to 3,789.7 thousand tonnes by the year 2030 . Similarly, the demand for wheat and pulses are also set to increase, the respective projections being 627.0 thousand tonnes and 488.7 thousand tonnes. While the demand for edible oils would rise to 395.5 thousand tonnes, demand for vegetables and fruits would expand to 3,551.4 thousand tonnes and 2639.2 thousand tonnes, respectively.

More than the absolute figures of projections, it is the projected annual rate of growth in demand for various commodities that would give a better idea on the relative pace at which demand for these commodities is expected to grow in future. The growth rate projections, presented in Table 8 , give a clear indication that diversification of food basket in Kerala would advance further with higher pace of growth in

Table 7. Projected total demand for major food commodities in Kerala, 2010-2030

('000 tonnes)

\begin{tabular}{lccccc}
\hline Commodity & 2010 & 2015 & 2020 & 2025 & 2030 \\
\hline Rice & 3567.5 & 3630.6 & 3693.8 & 3746.1 & 3789.7 \\
Wheat & 533.4 & 568.7 & 594.1 & 612.7 & 627.0 \\
Pulses & 433.6 & 453.5 & 468.5 & 479.8 & 488.7 \\
Edible oil & 305.8 & 340.6 & 364.8 & 382.2 & 395.5 \\
Vegetables & 2792.7 & 3086.9 & 3291.6 & 3438.9 & 3551.4 \\
Fruits & 1855.9 & 2158.7 & 2370.1 & 2522.7 & 2639.2 \\
Spices & 297.7 & 354.2 & 394.1 & 423.0 & 445.1 \\
\hline
\end{tabular}


Table 8. Projected annual growth in total demand for major food commodities in Kerala

(Per cent)

\begin{tabular}{lcccc}
\hline Commodity & $2010-15$ & $2015-20$ & $2020-25$ & $2025-30$ \\
\hline Rice & 0.35 & 0.35 & 0.28 & 0.23 \\
Wheat & 1.29 & 0.88 & 0.62 & 0.46 \\
Pulses & 0.90 & 0.66 & 0.48 & 0.37 \\
Edible oils & 2.19 & 1.38 & 0.94 & 0.69 \\
Vegetables & 2.03 & 1.29 & 0.88 & 0.65 \\
Fruits & 3.08 & 1.88 & 1.25 & 0.91 \\
Spices & 3.55 & 2.14 & 1.42 & 1.02 \\
\hline
\end{tabular}

demand for high-value commodities. The rice demand is expected to grow at a slow pace of 0.35 per cent per annum between 2010 and 2020. The speed of growth would reduce further to 0.28 per cent and 0.23 per cent per annum between 2020-25 and 2025-30, respectively. However, the demand for wheat would increase at a much higher rate of 1.29 per cent between 2010 and 2015, though this rate would slow down to 0.46 per cent between 2025 and 2030. Pulse demand would grow at a modest range of $0.37-0.90$ per cent during the next two decades. However, other commodities like edible oils, vegetables, fruits, spices, etc. would experience a real boost in consumption with growth estimates ranging from 1-3 per cent during 2010-2020, and nearly 1 per cent thereafter.

\section{Future Outlook on Food Self-sufficiency}

As noted above, the demand for food is increasing steadily and more so for high-value commodities. This has significant implications for the state's development planning, as contrasting growth scenarios of demand and supply could aggravate its level of self-sufficiency and harm the interests of a variety of agro-based industries that depend on agriculture for raw materials. The baseline demand projections show that rice demand would increase modestly during the next two decades. With the present level of self-sufficiency at just 17 per cent, there is a considerable scope to increase production of this staple food crop. Though productivity of the crop is showing upward trends, losing area under the crop could pose serious challenges. Estimates show that the production of rice should increase at 0.30 per cent per annum (Table 9) for the next two decades to maintain the present level of self-sufficiency by 2030. Should this be at 50 per cent of the projected demand in 2030, the growth in
Table 9. Projected annual supply growth required for major food commodities in Kerala

(Per cent)

\begin{tabular}{lcc}
\hline Commodity & \multicolumn{2}{c}{$\begin{array}{r}\text { Projected annual supply growth } \\
(2010-2030)\end{array}$} \\
\cline { 2 - 3 } & $\begin{array}{l}\text { prequired for } \\
\text { self-sufficiency }\end{array}$ & $\begin{array}{c}50 \text { per cent } \\
\text { self-sufficiency }\end{array}$ \\
\hline Rice & 0.30 & 5.68 \\
Wheat & $\mathrm{NA}$ & $\mathrm{NA}$ \\
Pulses & 0.62 & 22.75 \\
Edible oils & $\mathrm{NA}$ & $\mathrm{NA}$ \\
Vegetables & 1.29 & 2.81 \\
Fruits* & 0.46 & 0.46 \\
Spices & 2.19 & 3.86 \\
\hline
\end{tabular}

Note: *100 per cent level of self-sufficiency was assumed in case of fruits.

production required is much higher at 5.7 per cent per annum. Therefore, the future level of self-sufficiency in rice would depend a lot on how the area under its cultivation is managed and to what extent, research and extension machineries are deployed to improve or at least maintain yield growth.

Pulse production in Kerala is meager and the state is depending mostly on imports to meet consumers' demand. This scenario would continue in the future as well, given the subsistence nature of pulse farming in the state. Even to maintain the present level of selfsufficiency at nearly 1 per cent of what is demanded, pulse production needs to attain an annual growth of 0.62 per cent.

Coconut is the main source of vegetable oil in Kerala. Apart from coconut oil, other edible oils like 
sesame oil, sunflower oil, soybean oil, palm oil, etc. also find place in Kerala's culinary table, though most of them are not produced in the state. The import of palm oil has witnessed a surge in the recent years, given its strong price competitiveness in relation to coconut oil and other domestically produced oils. However, there are no proper estimates available on the annual imports of palm oil into Kerala. Nevertheless, coconut still dominates as the major source of oil for the state, particularly due to the consumers' preference for it for their household needs. It is projected that Kerala's total demand for edible oils would grow at an annual rate of 1-2 per cent in the coming decades. Notwithstanding this, coconut, the only major oil producing crop in Kerala is facing stagnation in its production for the past many years. Area under coconut declined marginally at the rate of 1.86 per cent per annum during the previous decade, thereby limiting the growth in its production at a meager rate of 0.42 per cent per annum. This may have serious implications for the stakeholders in the sector and can aggravate the state's import dependence for edible oils.

The demand for vegetables in Kerala has been increasing at a consistent pace that translates to around 1.15 per cent growth at an annual rate during 20102030. The declining trend in vegetable area at an alarming rate of 16.1 per cent per annum between 200001 and 2010-11 throws grim prospects for future if no interventions are made. There is a strong need to arrest area decline and improve productivity of vegetables so that at least the present level of self-sufficiency (37\%) is maintained which is possible if the crop registers an annual growth of 1.29 per cent in the next two decades.

Estimates presented above show that, fruit production in Kerala is presently in excess of what is demanded by around 35 per cent. Though banana, one of the major fruit crops in the state has maintained area under it during the previous decade, overall area under fruit crops has experienced a gradual decline. Area under mango has gone down at a considerable pace with commensurate shrinkage in production too. Similar trends were noticed in papaya, pine apple and other perennial fruit crops during the past one decade (GoK, 2012). Given the growing demand, fruit production would remain profitable even in the longrun, provided efficient methods of cultivation are practised. Therefore, farmers of Kerala need to be trained to capitalize on this imminent opportunity.
Spice sector in Kerala had to tread through a testing time during the past one decade or so. Even though Kerala is a major contributor of India's high-value spice exports, especially pepper, ginger, cardamom, etc., the state is not self-sufficient when it comes to overall spices. Almost all of red chilly being consumed in Kerala is imported from neighbouring states like Andhra Pradesh, Tamil Nadu, etc. Therefore, the need for protecting these valued niche crops for Kerala not only arises from the food security point of view, but also from the angle of protecting the livelihood of people who depend on these crops and in checking the drain on foreign exchange.

\section{Concluding Remarks}

The study has revealed that Kerala has already lost a considerable area under essential food crops like paddy, pulses, tapioca, vegetables, etc. The real estate boom that started bubbling a few years ago for facilitating rapid urbanization in the state precipitated the farm-land crisis and resulted in loss of area even under high-value crops like cashewnut, spices, tea, coffee, etc. The high level of returns obtained from commercial crops and non-agriculture sector are being used for funding imports from other states to meet the daily demand for food commodities. Even though the state has so far been successful in procuring its essential requirements on a day-to-day basis, there are concerns about its growing dependence on outside sources that may not be sustainable in the long-run.

The projections for supply-demand balance of food commodities undertaken in this study also reinforce the contention that Kerala's self-sufficiency in most of the food commodities would touch the worst levels, if the existing trends are allowed to continue for long. However, there are counter arguments that Kerala is part of a larger country and can afford to lay its focus on high income earning alternatives (Kannan, 2011). Past studies have also shown that, in spite of high level of food dependency, Kerala is one of the least food insecure states in India due to the high purchasing power of its residents and a well-functioning public distribution system (MSSRF, 2008).

Notwithstanding the above arguments, it is advisable to maintain certain basic level of selfsufficiency in essential food commodities, for the reasons listed hereafter. First, there is sufficient 
evidence that social exclusion and inequality in distribution of wealth in the state is rising and there is a need to protect this vulnerable population in times of scarcity; Second, the food exporting states have serious problems of food insecurity themselves, which may exacerbate further in future (Tharamangalam, 2011); Third, there is no guarantee that Kerala would continue to sustain its high purchasing power because a large part of this affluence is sourced by remittances from abroad, which has no stability. Fourth, the bargaining power of the state on key matters of sovereignty could be substantially compromised when it does not have the minimum level of food self-sufficiency, as is anticipated in near future. Therefore a comprehensive agricultural development strategy giving due considerations on the issues of comparative advantage, competitiveness, resource availability, urbanization, etc., is urgently called for.

\section{Acknowledgements}

The author sincerely thanks Dr Ramesh Chand, Dr Aradhna Aggarwal, Dr P. Kumar and Dr Bornali Bhandari for their guidance and inputs in shaping-up the paper. He is grateful to the anonymous referee for comments and suggestions.

\section{References}

Balakrishnanan, Pulapre (2008) Imagining an economy of plenty in Kerala. Economic and Political Weekly, 43 (20): 14-15.

Chakraborty, Achin (2005) Kerala's changing development narratives. Economic and Political Weekly, 40 (6): 541547.

CSO (Central Statistical Organization) (various years) National Accounts Statistics. Ministry of Statistics and Programme Implementation, Government of India, New Delhi.

GoK (Government of Kerala) (2012) Farm Guide. Farm Information Bureau, Department of Agriculture.

Harilal, K.N. and Joseph, K.J. (2003) Stagnation and revival of Kerala economy: An open economy perspective. Economic and Political Weekly, 38(23): 2286-2294.

Jeromi, P.D. (2003) What ails Kerala's economy: A sectoral exploration. Economic and Political Weekly, 38 (16): 1584-1600.

Jeromi, P.D. (2005) Economic reforms in Kerala. Economic and Political Weekly, 40 (30): 3267-3277.
Joshi, P.K., Birthal, P.S. and Minot, Nicholas (2006) Sources of Agricultural Growth in India: Role of Diversification towards High Value Crops. MTID Discussion paper No. 98. International Food Policy Research Institute, Washington, D.C.

Joshi, P.K., Chauhan, Sonia and Singh, Harvider (2008) Can horticulture revitalize Agricultural Growth? Indian Journal of Agricultural Economics, 63(3): 310-321.

Kannan, K.P. (1990) Kerala economy at the cross roads? Economic and Political Weekly, 25 (35): 1951-56.

Kannan, K.P. (1999) Rural labor relations and development dilemmas in Kerala: Reflections on the dilemmas of a socially transforming labor force in a slowly growing economy. Journal of Peasant Studies, 26 (2-3): 140181.

Kannan, K.P. (2005) Kerala's turnaround in growth: Role of social development, remittances and reform. Economic and Political Weekly, 40(6): 548.

Kannan, K.P. (2011) Agricultural development in an emerging non-agrarian regional economy: Kerala's challenges. Economic and Political Weekly, 46 (9): 6470.

Kumar, Praduman and Mittal, Surabhi (2006) Agricultural productivity trends in India: sustainable issues. Agricultural Economics Research Review, 19: 71-88.

Kumar, Praduman, Mruthyunjaya and Dey, Madan M. (2007) Long-term changes in food basket and nutrition in India. Economic and Political Weekly, 42 (35): 35673572.

Kumar, Praduman, Kumar, Anjani, Shinoj, P. and Raju, S.S. (2011) Estimation of demand elasticities for food commodities in India. Agricultural Economics Research Review, 24 (1): 1-14.

Mohanakumar, S. and Sharma, R.K. (2006) Analysis of farmer suicides in Kerala. Economic and Political Weekly, 41 (16): 1553-1558.

MSSRF (MS Swaminathan Research Foundation) (2008) Report on the State of Food Insecurity in Rural India. Chennai.

Nair, K.N. and Menon, Vineetha (2006) Lease farming in Kerala: Findings from micro level studies. Economic and Political Weekly, 41 (26): 2732-2738.

Oommen, M.A. (2008) Reforms and the Kerala model. Economic and Political Weekly, 43 (2): 22-25.

Parayil, Govindan (1998) The perils of trying to be objective without being reflective: The Kerala Model revisited? Bulletin of Concerned Asian Scholars, 30(3): 28-31. 
Prakash, B.A. (1998) Gulf migration and its economic impact - The Kerala experience. Economic and Political Weekly, 33(50): 3209-3213.

Scaria, Suma (2010) Changes in land relations: The political economy of land reforms in a Kerala village. Economic and Political Weekly, 45 (26\&27): 191-198.

Shinoj, P. and Mathur, V.C. (2007) Analysis of demand for major spices in India. Agricultural Economics Research Review, 19(2): 367-376.

Tharamangalam, Joseph (1998) The perils of social development without growth: the development debacle of Kerala. Bulletin of Concerned Asian Scholars, 30(1): 22-34.

Tharamangalam, Joseph (2011) Is food insecurity in Kerala a myth? Economic and Political Weekly, 46 (20): 6971.

Zachariah, K.C. and Irudaya Rajan, S. (2007) Migration Remittances and Employment: Short -term Trends and Long-term Implications. Working Paper No. 395. Centre for Development Studies, Trivandrum.

\section{Appendix 1. Methodology for computation of TFP of crops}

The Divisia Tornqvist or translog index of TFP used in the present study for computing the total output, total input and TFP indices by commodity under different locations is as given below:

Total output index (TOI)

$\mathrm{TOI}_{\mathrm{t}} / \mathrm{TOI}_{\mathrm{t}-1}=\Pi_{\mathrm{j}}\left(\mathrm{Q}_{\mathrm{jt}} / \mathrm{Q}_{\mathrm{jt}-1}\right)^{\left(\mathrm{R}_{\mathrm{jt}}+\mathrm{R}_{\mathrm{jt}-1}\right)^{1 / 2}}$

Total input index (TII)

$\mathrm{TII}_{\mathrm{t}} / \mathrm{TII}_{\mathrm{t}-1}=\Pi_{\mathrm{i}}\left(\mathrm{X}_{\mathrm{it}} / \mathrm{X}_{\mathrm{it}-1}\right)^{\left(\mathrm{S}_{\mathrm{it}}+\mathrm{S}_{\mathrm{it}-1}\right)^{1 / 2}}$

where,

$R_{j t}$ is the share of ' $j$ 'th output in total revenue,

$Q_{j t}$ is the output of ' $j$ 'th commodity,

$S_{i t}$ is the share of ' $i$ ' th input in total input cost,

$X_{i t}$ is quantity of ' $\mathrm{i}$ ' th input, and

$t$ is the time period.

For the productivity measurement over a long period of time, chaining indexes for successive time periods is preferable. With Chain-linking, an index is calculated for two successive periods $t$ and $t-1$, over the whole period $t_{0}$ to $T$ (sample from time $t=0$ to $t=T$ ) and the separate indexes are then multiplied together as shown below:

TOI $(t)=$ TOI (1).TOI(2)............. TOI $(t-1)$.

$\operatorname{TII}(t)=\operatorname{TII}(1) \cdot \operatorname{TII}(2) \ldots \ldots \ldots \ldots \ldots . \operatorname{TII}(t-1)$.

Total factor productivity (TFP) index

$\mathrm{TFP}_{\mathrm{t}}=\left(\mathrm{TOI}_{\mathrm{t}} / \mathrm{TII}_{\mathrm{t}}\right)$

Chain-linking index takes into account the changes in relative values/costs throughout the study period. This procedure has the advantage that no single period plays a dominant role in determining share weights and biases are likely to be reduced.

In the present context, the cost estimates and other data on the quantity and value of inputs provided by the Department of Economics and Statistics, Government of Kerala, corresponding to the period, 2000-01 to 2009-10 was used for TFP estimation. 


\section{Appendix 2. Estimation and future projection of demand}

This involves estimation of demand for the base-year of projection, estimation of income elasticity of demand for the specific commodity in question and projecting the future demand for the period for which the plan is to be framed. The base-year total demand for the commodity is generally estimated from the sample survey estimates on household per capita consumption. National Sample Survey Organization (NSSO) collects and compiles household data on consumer expenditure and consumption pattern by conducting nationwide surveys in India. The latest NSSO data on household consumption for Kerala is available for the year 2009-10. These data were utilized to estimate base-year demand of major food commodities like rice, pulses, vegetables, fruits, milk, etc. The income elasticities of demand for these commodities were collected from published literature and are given in Appendix 4. Finally, the projected demand for the commodity for the future period (2030 in this case) was estimated using the following formula;

$$
\begin{aligned}
& d_{t}=d_{t 0}\left(1+y_{g} \cdot e_{i}\right) \\
& D_{t}=d_{t} \cdot N_{t}
\end{aligned}
$$

where, $d_{t}$ is the per capita consumption in the projected year $t, d_{t 0}$ is the per capita demand for the base-year, $y_{g}$ is the growth in income and $e_{i}$ is the income elasticity of demand. $D_{t}$ is the total demand for the projected period and $N_{t}$ is the projected population for the future year $t$.

Appendix 3. Projected population and per capita income in Kerala, 2010-2030

\begin{tabular}{lcccccc}
\hline Year & $\begin{array}{c}\text { Rural } \\
\text { ('000 Nos) }\end{array}$ & $\begin{array}{c}\text { Urban } \\
\text { ('000 Nos) }\end{array}$ & $\begin{array}{c}\text { Total } \\
\text { ('000 Nos) }\end{array}$ & $\begin{array}{c}\text { Annual growth } \\
\text { rate (\%) }\end{array}$ & $\begin{array}{c}\text { Per capita income } \\
\text { (₹ at 2004-05 prices) }\end{array}$ & $\begin{array}{c}\text { Annual growth } \\
\text { rate (\%) }\end{array}$ \\
\hline 2010 & 25539 & 8778 & 34317 & 0.75 & 56107 & 8.33 \\
2015 & 26475 & 8998 & 35473 & 0.61 & 76859 & 5.71 \\
2020 & 27250 & 9160 & 36410 & 0.47 & 97674 & 4.45 \\
2025 & 26560 & 10572 & 37132 & 0.35 & 118485 & 3.64 \\
2030 & 24557 & 13152 & 37709 & 0.27 & 139296 & 3.08 \\
\hline
\end{tabular}

Source: Report of the Technical Group on Population Projections, Office of the Registrar General \& Census Commissioner, Government of India.

The per capita income was projected using ARIMA model.

\section{Appendix 4. Income elasticity of demand used for demand projections}

\begin{tabular}{lcc}
\hline \multirow{2}{*}{ Commodity } & \multicolumn{2}{c}{ Income elasticity of demand } \\
\cline { 2 - 3 } & All India & Kerala \\
\hline Rice & 0.02 & -0.06 \\
Wheat & 0.08 & 0.12 \\
Pulses & 0.22 & 0.05 \\
Edible oil & 0.29 & 0.29 \\
Vegetables & 0.26 & 0.26 \\
Fruits & 0.36 & 0.46 \\
Spices & 0.52 & 0.55 \\
\hline
\end{tabular}

Source: All India elasticities were taken from Kumar et al. (2011); Shinoj and Mathur (2007).

Kerala specific elasticities were derived through calibrations based on NSSO consumption data for Kerala. 